\title{
miR-372 (rs12983273) and LncRNA HULC (rs7763881) Genetic Polymorphisms and Susceptibility to Hepatitis B Virus (HBV) Infection
}

roba talaat ( $\sim$ roba.talaat@gebri.usc.edu.eg )

University of Sadat City https://orcid.org/0000-0002-1176-2727

\section{Samar M. Shahen}

University of Sadat City

Soha Z. Elshenawy

National Liver Institute: Menoufia University National Liver Institute

Salwa E. Mohamed

University of Sadat City

\section{Research Article}

Keywords: HBV, miR-372, HULC, Polymorphism, SNP

Posted Date: July 9th, 2021

DOI: https://doi.org/10.21203/rs.3.rs-656527/v1

License: (c) (i) This work is licensed under a Creative Commons Attribution 4.0 International License. Read Full License 


\section{Abstract}

MicroRNAs (miRNAs) and Long non-coding RNAs (IncRNAs) are two major types of non-coding RNAs (ncRNAs) with regulatory roles. Genetic variation in the miRNAs and IncRNAs has been involved in the initiation and progression of many diseases. miRNA-LncRNA interactions are implicated in the regulation of many diseases, such as hepatitis infection. In this study, we assumed that single nucleotide polymorphisms (SNPs) in miR-372 (rs28461391 C/T) and HULC (rs7763881 A/C) might participate in HBV infection risk. SNPs rs28461391 in miR-372 and rs7763881 in HULC were genotyped in 100 HBV patients and 100 healthy controls using the Polymerase chain reaction sequence-specific primer technique (PCR-SSP). Our results showed no significant difference in miR-372 rs12983273 genotype distribution between both controls and HBV patients. On the other hand, there was a significant increase in HULC rs7763881 CC genotype $(P<0.05)$ coincides with a significant decrease in AC genotype distribution $(\mathrm{P}<0.05)$ in HBV patients as compared to controls. Our results showed that the CC genotype is associated with an increased risk of HBV infection (OR=3.43; $\mathrm{Cl}$ : 1.3-9.07) while AA genotype is a protective one (OR= 0.3; $\mathrm{Cl}$ : 0.13-9.07). Our results suggest that HULC rs7763881 A/C might be a biomarker for HBV susceptibility. However, larger sample studies are recommended to verify our preliminary data. To the best of our knowledge, the present study was the first to investigate the relevance of miR-372 (rs28461391 C/T) and HULC (rs7763881 A/C) gene polymorphisms to the risk of HBV infection in the Egyptian population.

\section{Introduction}

The hepatitis B virus (HBV) is a major health problem resulting in substantial human morbidity and mortality [1]. Worldwide HBV infection is a crucial risk factor for chronic hepatitis, liver cirrhosis, and hepatocellular carcinoma (HCC) [2]. HBV has affected almost one-third of the world's population and, of them, more than 350 million people have developed chronic HBV infection [3]. Egypt pertains to the intermediate endemic countries where the prevalence of HBV ranges from 2-8 \% of the population. Nearly 2-3 million Egyptians are chronic carriers of HBV [4].

Human genomes transcribe up to $90 \%$ of the genomic DNA [5]. Only 1-2\% of these transcripts encode for proteins, whereas the vast majority are transcribed as non-coding RNAs (ncRNAs) [6,7]. According to their size (with 200 nucleotides as a cut-off), ncRNAs can be divided into two classes; short ncRNAs including microRNAs (miRNAs) and long non-coding RNAs (IncRNAs) [8,9]. However, they are not translated into protein products; they exert essential functions within the cell by amending the expression of protein-coding mRNAs, interacting with proteins to affect their function, and act reciprocally to tune their expression $[\mathbf{1 0 , 1 1 ] .}$

miRNAs comprise small non-coding RNAs of approximately 22 nucleotides regulating gene expression at the posttranslational level through imperfectly base pairing with the 3'-untranslated regions (3'-UTRs) of target mRNAs, thereby participating in critical biological processes, including cell proliferation, differentiation, and apoptosis [12]. miRNA expression profile in hepatic tissues or circulation alters due to 
viral infection [13]. miRNAs can modulate HBV replication by targeting HBV-associated host proteins [14]. miRNA-372 stimulated the production of HBV proteins and HBV core-associated DNA by targeting nuclear factor $\mathrm{I} / \mathrm{B}[15,16]$.

IncRNAs are non-protein coding transcripts that range from 200 bases to $100 \mathrm{~kb}$, involved in all aspects of gene regulation and biological processes [17]. IncRNAs involve signals, guides, decoys, or scaffolds [18]. Several IncRNAs are playing relevant roles in viral infection and the antiviral response [19].

LncRNAs can act as molecular microRNA decoys or sponges, sequestrating microRNAs favoring the expression of repressed target mRNAs [20]. Other IncRNAs depress gene expression by competing with miRNAs for interaction with shared target mRNAs [21]. Finally, some IncRNAs can produce miRNAs, leading to repression of target mRNAs [22]. These microRNA-IncRNA regulatory paradigms modulate gene expression patterns that drive major cellular processes [23]. Highly Up-regulated in Liver Cancer (HULC) is about $1.6 \mathrm{k}$ nucleotide long, containing two exons but not translated, detected in gastric cancer and colorectal carcinomas that metastasize to the liver [24,25]. HULC acts as an endogenous sponge of miR-372 by sequestering it away from potential mRNA target [26].

Since gene polymorphism may have different effects in diverse populations, this case-control study looks forward to detecting the possible genetic alteration in miR-372 and HULC genes that contributed to the association between these SNPs the risk of HBV persistent infection in the Egyptian population. We further evaluated the gene-gene interaction between both genes.

\section{Materials And Methods}

\section{Patient characteristics and study design}

One hundred patients with HBV Infection were included in this study, recruited from the National Liver Institute (NLI), Menoufiya University, Egypt. All patients with chronic HBV infection (CHB) fulfilled the diagnostic criteria: positive for hepatitis B surface antigen ( $\mathrm{HBsAg}$ ) for six months or more along with serum HBV, DNA with more than $10^{5} \mathrm{copies} / \mathrm{ml}$. HCV patients or any viral or liver diseases were excluded from the study. Viral assessment in all subjects was performed as previously described in Motawi et al. (2019) [27]. One hundred healthy controls with normal liver function tests and no history of previous liver disease and negative HBV and HCV serology were enrolled in the study. This study was approved by Health and Human Ethical Clearance Committee guidelines for Clinical Researches, and following recruitment, the subjects gave informed consent for genetic analysis. The Health and Human Ethical Clearance Committee of the National Liver Institute (NLI) approved the study. All the subjects who participated in the study provided informed consent.

\section{DNA isolation}

Venous blood $(5 \mathrm{ml})$ from each individual involved in this study was collected on ethylene-diamine-tetraacetic acid (EDTA) sterile vacutainer. According to the manufacturer's instructions, genetic DNA was 
extracted from whole blood-EDTA samples by the Gentra Puregene Blood Kit (Qiagen Company, Hilden, Germany). Extracted DNA was applied to 1\% agarose gel to confirm its integrity. The concentration and purity of DNA in all samples were measured using NanoDrop ${ }^{\text {TM }}$ 2000/2000c Spectrophotometer (Thermo Fisher Scientific, Waltham, MA, USA).

\section{Genotyping}

miR-372 (rs28461391 C/T) and HULC (rs7763881 A/C) primer sequences and DNA fragments characterizing each genotype/allele are presented in Table (1). Primer sequences used were designed using primosnp 3.4 software (http://www.changbioscience.com/primo/ primosnp.html) then checked using primer blast (http://www.ncbi.nlm.nih.gov/tools/primer-blast). All polymerase chain reactions (PCR) were performed in the 2720 thermal cycler (Applied Biosystems). miR-372 and HULC were genotyped by sequence-specific primer-PCR (SSP-PCR). The PCR reaction was done in two tubes, one for each allele. Each reaction mixture consisted of DreamTaq Green Master Mix (2x) (Fermentas, Thermo Fisher Scientific Inc.), 10 pmoles of each allele-specific primer, 10 pmoles of reverse primer, and 150 ng of template DNA.

The cycling conditions of PCR for miR-372 (rs28461391 C/T) were as follows: $94{ }^{\circ} \mathrm{C}$ for 5 min ( 1 cycle), followed by $94^{\circ} \mathrm{C}$ for $30 \mathrm{~s}, 58^{\circ} \mathrm{C}$ for $30 \mathrm{~s}$, and $72^{\circ} \mathrm{C}$ for the $30 \mathrm{~s}$ (35 cycles) and a final extension step at $72^{\circ} \mathrm{C}$ for $7 \mathrm{~min}$. The size of the PCR product was $517 \mathrm{bp}$. For HULC (rs7763881 A/C), PCR the cycling conditions were as follows: $94^{\circ} \mathrm{C}$ for $5 \mathrm{~min}(1 \mathrm{cycle})$, followed by $94^{\circ} \mathrm{C}$ for $30 \mathrm{~s}, 58^{\circ} \mathrm{C}$ for $45 \mathrm{~s}$, and $72^{\circ} \mathrm{C}$ for $30 \mathrm{~s}$ (10 cycles) and a final extension step at $72^{\circ} \mathrm{C}$ for $7 \mathrm{~min}$. The size of the PCR product was $234 \mathrm{bp}$.

\section{Statistical analysis}

Statistical analysis was performed using the Statistical Package for Social Science (SPSS) version 19 (IBM Corporation, USA). Comparisons were made using an independent test, and results were presented as mean \pm SD. Comparisons among numerical variables between HBV and controls for quantitative variables were performed by independent t-test. SNP/STAT was performed using the online tool (http://bioinfo.iconcologia.net/SNP stats). Odds ratios (OR with 95\% Cl) were calculated to measure the relative risks in both control and HBV patients. Gene-gene Interaction was calculated by Multifactor dimensionality reduction software for detecting gene-gene (MDR). All values were two-tailed, and $\mathrm{P}<0.05$ were considered to be statistically significant.

\section{Results}

\section{Patient's characteristics}

The demographic and biochemical characteristics of control and HBV patients are shown in Table (2). The HBV patients group showed a significant increase in liver enzyme levels (AST and ALT), direct and total bilirubin, urea, and creatinine levels $(P<0.001)$. A significant decrease in the level of albumin $(P<0.001)$ was demonstrated. 


\section{miR-372 (rs12983273C/T) and HULC (rs7763881 A/C) polymorphisms}

The genotype of miR-372 rs12983273C/T showed that the TC genotype is the most frequent in both groups ( $88 \%$ vs. $93 \%$ in control and HBV, respectively). Genotype frequencies were $3 \%$ (CT), $88 \%$ (TT), and $9 \%$ (TT) in the controls and $3 \%$ (CC), $93 \%$ (CT), and $4 \%$ (TT) in the patients (Table 3). No statistically significant difference was demonstrated in genotype distribution in both controls and HBV patients, suggesting that miR-372 rs 12983273 polymorphism may not be associated with HBV infection risk.

HBV patients had increased frequency of HULC CC genotypes (AA, AC, CC $=1 \%, 80 \%, 19 \%$; respectively) vs controls (AA, AC, $C C,=1 \%, 93 \%, 6 \%$; respectively). CC genotype distribution showed statistically significant increase $(P<0.05)$ while $A C$ genotype distribution was statistically decreased $(P<0.05)$ in HBV patients as compared to controls (Table 3 ). This indicating that CC genotype might be considered as risk factor $(\mathrm{OR}=3.43$; $\mathrm{Cl}$ : 1.3-9.07) while $\mathrm{AC}$ genotype might be a protective factor $(\mathrm{OR}=0.3 ; \mathrm{Cl}$ : $0.13-9.07)$ for susceptibility of HBV infection.

There was linkage disequilibrium between miR-372 C/T and HULC A/C SNPs with a D' value of 0.846 and $r^{2}$ (the coefficient of determination) value of 0.6093 . We employed the MDR to screen the gene-gene interaction combination between both SNPs. The cross-validation consistency of the two-locus models was $10 \backslash 10$, and both loci had training and testing accuracy of 0.5 (Figure 1 )

\section{Discussion}

$\mathrm{HBV}$ infection is a major global public health problem. The consequence of HBV infection is highly diverse, including acute hepatitis, self-limiting recovery, chronic hepatitis, cirrhosis, liver cancer, ending with liver failure [28]. Several host genes may play essential roles in HBV infection [29,30]. Although ncRNA isn't translated into proteins, they regulate various cellular functions and processes through controlling gene expression [11]. The most prevalent ncRNAs are miRNAs and LncRNAs. Many studies have shown that miRNAs are involved in modulating gene expression and replicating HBV and play a pivotal role in host-virus interactions $[28,31]$. Therefore, genetic polymorphisms of miRNA genes can influence viral infection susceptibility [32,33].

Concerning an SNP in miR-372 rs $12983273 \mathrm{C} / \mathrm{T}$, regardless of the increased TC frequency in HBV patients, our genotyping results showed an insignificant difference between genetic variation of miR-372 rs12983273C/T and susceptibility to HBV infection. Our results follow Kwak et al. (2012) [30], who demonstrated no association between miR-372 rs12983273C/T polymorphism and resolution of HBV infection.

Viruses have several strategies to increase the efficacy of replication and fight the antiviral immune system. Expression of the cellular IncRNAs is altered in response to viral proteins' expression [34]. Several studies demonstrated that IncRNAs are involved in cancer development by regulating cancer-related gene expression, thus acting as oncogenes and tumor suppressors in many cancers [35,36]. One of these 
IncRNAs is HULC, which has been reported as an oncogene that is up-regulated in several cancers, including hepatocellular carcinoma (HCC) $[37,38]$. SNPs in cellular IncRNAs are associated with a viral infection and tumor risk. This study demonstrated the effect of genetic variation of HULC rs7763881 A/C on the susceptibility to hepatitis B infection.

In this study, SNP of HULC rs7763881 A/C showed that rs7763881 CC genotype was associated with an increased risk of HBV infection while rs7763881 AC genotype was protective. In accordance with this result, Liu et al. (2012) [39]. and Motawi et al. (2019) [40]. reported that the AC genotype is the most frequent in the Chinese population and Egyptian population, respectively. In contrast to our result, they said no significant association between HULC rs7763881 SNP between HBV natural clearance and HBV persistent carriers. However, the variant genotypes of rs7763881 in HULC may contribute to decreased susceptibility to HCC in HBV persistent carriers.

\section{Conclusion}

In conclusion, this preliminary study suggests that rs 7763881 of the HULC gene is associated with increased susceptibility to HBV infection while the protective effect is observed in AC carriers. The variant genotypes of miR-372 rs $12983273 \mathrm{C} / \mathrm{T}$ may contribute to disease susceptibility. However, future research should include a larger sample size to explore further the HULC gene's role in defining the susceptible subjects to viral infection.

\section{Declarations}

Funding: No funding was received for conducting this study.

Conflict of interest: The authors declare no conflict of interest.

\section{References}

1. Si J, Yu C, Guo Y, Bian Z, Meng R, Yang L, et al (2019) Chronic hepatitis B virus infection and total and cause-specific mortality: A prospective cohort study of 0.5 million people. BMJ 9(4): e027696.

2. Asgari S, Chaturvedi N, Scepanovic P, Hammer C, Semmo N, Giostra E, et al (2019) Human genomics of acute liver failure due to hepatitis B virus infection: An exome sequencing study in liver transplant recipients. Viral Hepat 26(2):271-277.

3. Jefferies M, Rauff B, Rashid,H, Lam ., Rafiq S (2018) Update on global epidemiology of viral hepatitis and preventive strategies. World J Clin. Cases 6(13):589-599.

4. Khaled IAEA, Mahmoud OM, Saleh AF, Bioumie EE (2011) Prevalence of HBV genotypes among Egyptian hepatitis patients. Mol Biol Rep 38(7):4353-4357. 
5. Kashi K, Henderson L, Bonetti,A, Carninci P (2016) Discovery and functional analysis of IncRNAs: Methodologies to investigate an uncharacterized transcriptome. Biochim Biophys Acta Gene Regul Mech 1859(1):3-15.

6. Kaikkonen MU, Lam MTY, Glass CK (2011) Non-coding RNAs as regulators of gene expression and epigenetics. Cardiovasc Res 90(3):430-440.

7. Bonetti A, Carninci P (2017). From bench to bedside: The long journey of long non-coding RNAs. Curr Opin Syst Biol 3: 119-124.

8. Fiannaca A, La Rosa M, La Paglia L, Rizzo R, Urso A (2017) NRC: Non-coding RNA Classifier based on structural features. BioData Min. 10: 1-18.

9. Diamantopoulos MA, Tsiakanikas P, Scorilas A (2018) Non-coding RNAs: the riddle of the transcriptome and their perspectives in cancer. Ann Transl Med 6 (12): 241-241.

10. Ling H, Fabbri M, Calin GA (2013) MicroRNAs and other non-coding RNAs as targets for anticancer drug development. Nat Rev Drug Discov 12 (11):847-865.

11. Yamamura S, Sumida MI, Tanaka Y (2018) Interaction and cross-talk between non-coding RNAs. Cell Mol Life Sci 75(3):467-484.

12. Gao L, Yang X, Zhang H, Yu M, Long J, Yang $T$ (2018) Inhibition of miR-10a-5p suppresses cholangiocarcinoma cell growth through downregulation of akt pathway. Onco Targets Ther 11: 69816994.

13. Ye D, Zhang T, Lou G, Liu Y (2018) Role of miR-223 in the pathophysiology of liver diseases. Exp Mol Med 50(9):1-12.

14. Sagnelli E, Potenza N, Onorato L, Sagnelli C, Coppola N, Russo A (2018) Micro-RNAs in hepatitis B virus-related chronic liver diseases and hepatocellular carcinoma. World Hepatol 10 (9):558-570.

15.Guo H, Liu H, Mitchelson K, Rao H, Luo M, Xie L, et al (2011) MicroRNAs-372/373 promote the expression of hepatitis B virus through the targeting of nuclear factor I/B. Hepatology 2:54(3):808-819.

16. Kitab B, Alj HS., Ezzikouri S, Benjelloun S (2015) MicroRNAs as Important Players in Host-hepatitis B Virus Interactions. J Clin Transl Hepatol 3 (2):149-161.

17. Fernandes JCR, Acuña SM, Aok, Jl, Floeter-Winter LM, Muxel SM (2019) Long non-coding RNAs in the regulation of gene expression: Physiology and disease. Non-coding RNA 17:5(1):17.

18. Leti F, DiStefano JK (2017) Long noncoding RNAs as diagnostic and therapeutic targets in type 2 diabetes and related complications. Genes (Basel) 8(8):207 
19. Siddiqui H, Al-Ghafari A, Choudhry H, Al Doghaither H (2019) Roles of long non-coding RNAs in colorectal cancer tumorigenesis: A review. Mol Clin Oncol 11(2): 167-172.

20. López-Urrutia E, Bustamante Montes LP, Ladrón de Guevara Cervantes D, Pérez-Plasencia C, CamposParra A D (2019) Crosstalk Between Long Non-coding RNAs, Micro-RNAs and mRNAs: Deciphering Molecular Mechanisms of Master Regulators in Cancer. Front Oncol 9:669

21. Fan CN, Ma L, Liu N (2018) Systematic analysis of IncRNA-miRNA-mRNA competing endogenous RNA network identifies four-IncRNA signature as a prognostic biomarker for breast cancer $11 \mathrm{Medical}$ and Health Sciences 1112 Oncology and Carcinogenesis. J Transl Med 16: 1-12.

22. Wang S, Ge W, Luo Z, Guo Y, Jiao B, Qu L, Zhang Z, Wang X (2017) Integrated analysis of coding genes and non-coding RNAs during hair follicle cycle of cashmere goat (Capra hircus). BMC Genomics 18 (1):767.

23. Dai X, Kaushi, AC, Zhang J (2019) The emerging role of major regulatory RNAs in cancer control. Front Oncol 9: 1-14.

24. Zhao Y, Guo Q, Chen J, Hu,J, Wang S, Sun, Y (2014) Role of long non-coding RNA HULC in cell proliferation, apoptosis and tumor metastasis of gastric cancer: A clinical and in vitro investigation. Oncol Rep 31(1):358-364.

25. Cao SQ, Zheng H, Sun BC, Wang ZL, Liu T, Guo .H, Shen ZY (2019) Long non-coding rna highly upregulated in liver cancer promotes exosome secretion. World J Gastroenterol 25 (35): 5283-5299.

26. Yang C, Wu D, Gao L, Liu X, Jin Y, Wang D, Wang T, Li X (2016) Competing endogenous RNA networks in human cancer: Hypothesis, validation, and perspectives. Oncotarget 7(12): 13479-13490.

27. Motawi TK, Mady AE, Shaheen S, Elshenawy SZ, Talaat RM, Rizk SM (2019) Genetic variation in microRNA-100 (miR-100) rs1834306 T/C associated with Hepatitis B virus (HBV) infection: Correlation with expression level. Infect Genet Evol [Internet] 73:444-9.

28. Zhang Z, Wang C, Liu Z, Zou G, Li J, Lu M (2019) Host genetic determinants of hepatitis B virus infection. Front Genet 10: 1-24.

29. Kwak MS, Lee DH, Cho Y, Cho EJ, Lee JH, Yu SJ, et al (2012) Association of polymorphism in primicroRNAs-371-372-373 with the occurrence of hepatocellular carcinoma in hepatitis B virus infected patients. PLoS One. 7(7): e41983.

30. Matsuura K, Isogawa M, and Tanaka Y (2016). Host genetic variants influencing the clinical course of Hepatitis B virus infection. J Med.Virol 88(3): 371-379.

31. Sarkar N, Chakravarty R (2015) Hepatitis B virus infection, MicroRNAs and liver disease. Int J Mol Sci 16(8): $17746-17762$. 
32. Han Y, Pu R, Han X, Zhao J, Zhang Y, Zhang Q, et al (2013) Associations of pri-miR-34b/c and pre-miR$196 \mathrm{a} 2$ polymorphisms and their multiplicative interactions with hepatitis $B$ virus mutations with hepatocellular carcinoma risk. PLoS One 8(3): e58564.

33. Al-Qahtani AA, Al-Anazi MR, Nazir N, Wani K, Abdo AA, Sanai FM, et al (2017) Association of single nucleotide polymorphisms in microRNAs with susceptibility to hepatitis B virus infection and HBV-related liver complications: a study in a Saudi Arabian population. J Viral Hepat 24(12):1132-1142.

34. Fortes P, Morris K V (2016) Long noncoding RNAs in viral infections. Virus Res [Internet]. 212:1-11. 35. Sanchez Calle A, Kawamura Y, Yamamoto Y, Takeshita F, Ochiya T (2018) Emerging roles of long noncoding RNA in cancer. Cancer Sci 109(7):2093-2100.

36. Hong JH, Jin EH, Chang IA, Kang H, Lee S II, Sung JK (2020) Association between IncRNA HULC rs7763881 polymorphism and gastric cancer risk. Pharmgenomics Pers Med 13:121-126.

37. Yang X, Xie X, Xiao YF, et al (2015) The emergence of long non-coding RNAs in the tumorigenesis of hepatocellular carcinoma. Cancer Lett 360(2):119-124.

38. Zhu Y, Zhang X, Qi L, et al (2016) HULC long noncoding RNA silencing suppresses angiogenesis by regulating ESM-1 via the PI3K/Akt/mTOR signaling pathway in human gliomas. Oncotarget 7(12):14429-14440.

39. Liu Y, Pan S, Liu L, Zhai X, Liu J, Wen J, Zhang Y, Chen J, Shen H, Hu Z (2012) A Genetic Variant in Long Non-Coding RNA HULC Contributes to Risk of HBV-Related Hepatocellular Carcinoma in a Chinese Population 7(4): 5-8.

40. Motawi TMK, El-Maraghy SA, Sabry D, Mehana NA (2019) The expression of long non coding RNA genes is associated with expression with polymorphisms of HULC rs7763881 and MALAT1 rs619586 in hepatocellular carcinoma and HBV Egyptian patients. J Cell Biochem 120(9):14645-14656.

\section{Tables}

Table 1. PCR primers Sequence used for amplification of miR-372 and HULC in HBV patients and controls 


\begin{tabular}{|c|c|c|}
\hline SNP & Primers & PCR Product \\
\hline miR-372 & Forward C: 5'-CCTGTGGTTTCGATTCCCAGC-3' & $517 p b$ \\
\hline \multirow[t]{2}{*}{ rs28461391 C/T } & Forward T: 5' CCTGTGGTTTCGATTCCCAG T-3' & \\
\hline & Reverse: $\quad$ 5'-GTGCATACAGCCCCTTGGT -3' & \\
\hline HULC & Forward A: 5'-TGTAGTTCCAGTTTGTCTGAA-3' & $234 \mathrm{pb}$ \\
\hline rs7763881 A/C & Forward C: 5' TGTAGTTCCAGTTTGTCTGAC-3' & \\
\hline & Reverse: 5'-TGAACAAGTTGGTTGATCTTTAGC-3' & \\
\hline
\end{tabular}

Table 2. Demographic and biochemical characteristics in controls and HBV patients

\begin{tabular}{|c|c|c|c|}
\hline Parameter & $\begin{array}{l}\text { Control } \\
(\mathrm{N}=100) \\
\text { (Mean } \pm \text { SD) }\end{array}$ & $\begin{array}{l}\text { HBV } \\
(\mathrm{N}=100) \\
(\text { Mean } \pm \text { SD) }\end{array}$ & P-value \\
\hline Gender (Female/Male) & $30: 70$ & $27: 73$ & NS \\
\hline AST (IU/L) & $20.939 \pm 5.802$ & $49.438 \pm 26.9742$ & $P<0.001$ \\
\hline ALT (IU/L) & 1. 4.900 & $49.801 \pm 32.6447$ & $P<0.001$ \\
\hline Albumin (g/L) & $4.281 \pm 0.3977$ & $3.305 \pm 0.6654$ & $P<0.001$ \\
\hline T- bill (mg/dl) & $0.664 \pm 0.1838$ & $1.39 \pm 0.9906$ & $P<0.001$ \\
\hline D- bill (mg/dl) & $0.112 \pm 0.1603$ & $0.614 \pm 0.9161$ & $P<0.001$ \\
\hline Urea (mg/dl) & $29.540 \pm 7.0931$ & $38.326 \pm 18.3218$ & $P<0.001$ \\
\hline Creatinine (mg/dl) & $0.890 \pm 0.1667$ & $1.877 \pm 0.4323$ & $P<0.001$ \\
\hline HBV-PCR & - & $1025070.924 \pm 5110607.6194$ & - \\
\hline
\end{tabular}


All data are showed as mean \pm standard deviation(SD), Aspartate amino transferase (AST); Alanine amino transferase (ALT); Total Billirubin (T-Bill): Direct Billirubin (d-Bill); International Units per liter (IU/L); Gram per liter ( $\mathrm{g} / \mathrm{L})$; Milligrams per Deciliter (mg/dL); Polymerase chain reaction (PCR).

Table 3. Genotype distribution of miR-372 (rs28461391 C/T) and HULC (rs7763881 A/C), in controls and HBV patients 


\begin{tabular}{|c|c|c|c|c|}
\hline Genotype & $\begin{array}{l}\text { Controls }(N=100) \\
N(\%)\end{array}$ & $\begin{array}{l}\text { HBV } \\
(\mathrm{N}=100) \\
\mathrm{N}(\%)\end{array}$ & OR $(95 \% \mathrm{Cl})$ & P-value \\
\hline \multicolumn{5}{|c|}{ miR-372 (rs28461391 C/T $)$} \\
\hline \multicolumn{5}{|c|}{ Genotype ( $(\underline{N}, \%)$. } \\
\hline $\mathrm{CC}$ & $3(3)$ & $3(3)$ & $1(0.19-5.07)$ & NS \\
\hline CT & $88(88)$ & $93(93)$ & $1.81(0.68-4.81)$ & NS \\
\hline TT & $9(9)$ & $4(4)$ & $0.42(0.12-1.41$ & NS \\
\hline CTTT & $97(97)$ & $97(97)$ & $1(.197-5.078)$ & NS \\
\hline \multicolumn{5}{|l|}{ Allele $(\underline{N}, \%)$} \\
\hline C & $94(47)$ & $99(49.5)$ & $1.1(0.746-1.63)$ & NS \\
\hline $\mathbf{T}$ & $106(53)$ & $101(50.5)$ & $0.904(0.611-1.33)$ & NS \\
\hline \multicolumn{5}{|c|}{ HULC (rs7763881 A/C). } \\
\hline \multicolumn{5}{|c|}{ Genotype (N,,$\underline{\text { o }}$. } \\
\hline AA & $1(1)$ & $1(1)$ & $1(0.06-16.21)$ & NS \\
\hline$A C$ & $93(93)$ & $80(80)$ & $0.30(0.12-0.74)$ & $P<0.01$ \\
\hline $\mathrm{CC}$ & $6(6)$ & $19(19)$ & $3.43(1.30-9.07)$ & $P<0.01$ \\
\hline ACCC & $99(99)$ & $99(99)$ & $1(.062-16.21)$ & NS \\
\hline Allele ( $(\underline{N}, \%)$. & & & & \\
\hline
\end{tabular}




\begin{tabular}{|lllll|}
$\mathbf{A}$ & $95(47.5)$ & $82(41)$ & $0.768(0.51-1.14)$ & NS \\
\hline $\mathbf{C}$ & $105(52.5)$ & $118(59)$ & $1.30(0.87-1.93)$ & NS \\
\hline
\end{tabular}

OR, odds ratio; $95 \% \mathrm{Cl}, 95 \%$ confidence interval. NS, non-significant.

\section{Figures}


miR-372

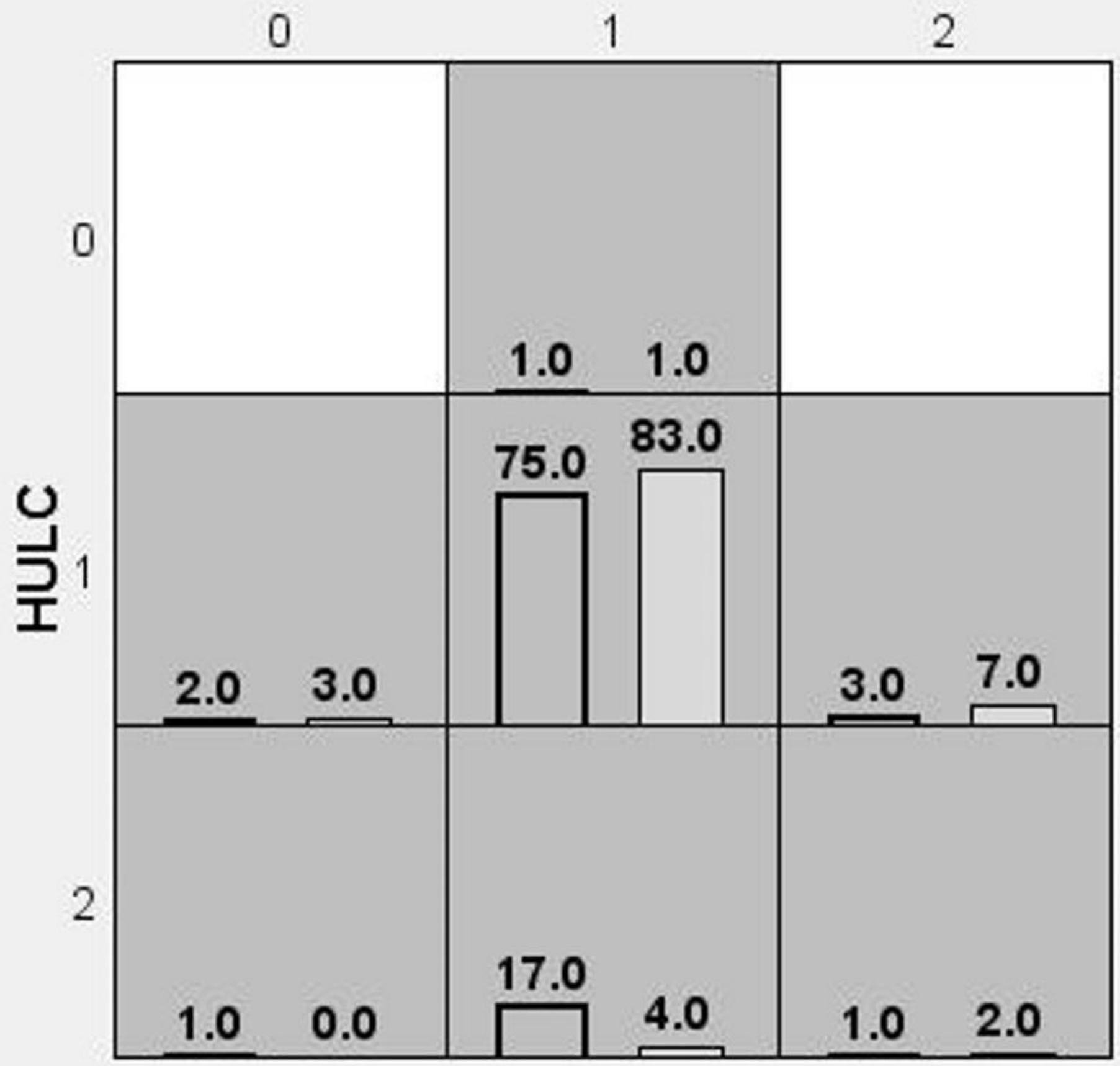

Figure 1

Gene - gene interaction between miR-372 and HULC. 